point out, say three inches, from the place of puncture. The gut is caught, the needle freed and withdrawn, and the part of the catgut bearing the silk being adjusted so as to occupy the middle of the track, the ends are cut short, and by putting the skin on the stretch they slip below it, thus making the whole piece subcutaneous. Of course the needle, surface of skin, \&c., are previously rendered antiseptic.

In this manner, then, I have performed about twenty experiments upon dogs and rabbits, latterly with the addition that I killed the animal by bleeding, and injected the abdominal aorta with two per cent. Bruke's soluble Prussian blue. I then cut out the pieces of catgut with some of the tissue in which they were imbedded, hardened them in spirit, or froze them, and made sections in the usual way.

The results of these experiments show that a gradual softening takes place from without in, the catgut breaking down and becoming infiltrated with cells, probably leucocytes. This part of the process takes from five days to about twenty, varying with the specimen of catgut, the tissue amongst which it is situated, and the age and vitality of the aximal. Next the pultaceous mass into which it has been converted begins to metamorphose, and is soon permeated with blood channels, and ultimately may be described as a cast of the catgut, in a kind of granulation tissue freely supplied with bloodvessels, which in many of my sections are very fully injected.

If, then, we admit these conclusions, we can easily account for the different results obtained by the use of catgut in different hands. We see that it is in reality merely a tem. porary ligature, because when in the softened stage we cannot consider it to have any constricting effect.

Whether, then, this temporary condition lasts long enough to produce embolic occlusion of the vessels depends upon the sample of catgut and the vitality of the patient.

In conclusion, my experiments seem to demonstrate that an aseptic, dead, foreign, animal body may under appropriate conditions become, by a process of softening, absorption, and re-deposition, changed into or replaced by a living, vascular, and comparatively highly organised, animal structure.

\section{THE PRIMARY CAUSES OF SEA-SCURVY.}

\section{Br HARRY LEACH, M.R.C.P.L,}

MEDICAL OFFICER OF HEALTH FOR THE POBT OF LONDON, AND PHYSICIAN TO TRE (DREADNOUGHT) SRAMEN'S HOSPITAL.

IT has been a subject of much annoyance to all interested in the hygienic condition of our merchant vessels that scurvy during the last eight or nine months has reappeared with renewed vigour among the crews of some ten or twelve long-voyage ships. Batehes of typical cases so familiar to the medical officers of the Dreadnought twenty years ago have again been seen at Greenwich, and I may safely state that British ships have brought home, since the commencement of the year, at least fifty cases of the disease, not taking into account about as large a number landed at ports abroad from the same cause. These facts are, in a scientific and also in an official aspect, very humiliating. The Merchant Shipping Act of 1867, some sections of which were specially drawn with a view to the prevention of scurvy, has hitherto been declared, on this score, a great success. But, in consequence of these recent ontbreaks, public faith in the existing legislative measures at present carried out is somewhat shaken. The result is of course inevitable, when it is considered that since these so-called antiscorbutic enactments came into operation, the gradual substitution of steam for sailing ships, the opening of the - Suez Canal, and the introduction into the export markets of a vast quantity and variety of preserved provisions, are all to be classed as so many powerful aoents in the extinction of sea-scurvy. Hence it appears desirable at the present time to recapitulate briefly the direct causes of the disease, leaving the reader to judge whether these cauges are, under existing commercial circumstances, preventable or not.

The late Dr. Parkes, whose practical interest in this sub. ject was constant, and whose article in the British and Foreign Medico-Chirurgical Review, published in 1848, has never been surpassed, asserted (and, as it appears to me, proved) that absence of vegetable diet was the one constant factor in the production of scurvy. The disease may not-indeed, does not-invariably occur when vegetables are not taken, but it may safely be said that when fresh vegetables are eaten, of good quality and fair in quantity, scurvy does not appear. Many cases are on record in which persons remained free from the disease for months together on an exclusively animal diet, the flesh eaten being, however, fresh and good of its kind and ample in quantity. The predisposing, or secondary, causes of scurvy on board ship are cold and damp clothes and quarters, an inactive life, dirty babits, in all probability bad water, an ${ }_{\text {, }}$ of course, pre existing illness I do not propose just now to enter at all into the scientific bearings of the question, or again to discuss the potash, phosphoric acid, citric acid, or other theories; but, being firmly convinced that these recent cargoes of scurvy need not have been imported into this country by our own ships, I am anxious to convince the profession and the public that one, or both, of the two direct causes above mentioned would be found to obtain in each and every case if opportunities were afforded for a thorough and complete examination. Dirt, idleness, "scouse," bad water, and "venereal," are all put forward as direct causes of the disease by shipmasters and shipowners, many of the latter never having "voyaged" at all in their own vessels. But dirt, as we all know, is common to very many individuals afloat and ashore, and if all idle people became scorbutic, scurvy would be endemic in every quarter of the globe. "Scouse" is a mixture composed of cook's fat, or slush biscuit, and water, to which minced salt meat is usually added. I will venture to assert that, in spite of prohibitions from the captain and obstructions from the cook, it is eaten habitually by at least three-fourths of all seamen in longvoyage ships, and, according to scientific evidence, has no specially scorbutic properties, assuming, of course, that the ingredients used are all fairly good of their kind. Bad water-and as may, I think, be added, condensed watermay possibly predispose to scurvy. But this has been often named as an exciting cause, whereas crews of other ships, supplied with the same water from the same place, have returned in good health. Venereal, or, indeed, any other disease, will always predispose to scurvy; but the presence of the former need not, and ought not, to herald the advent of the latter, unless the man is so ill as to be unfit for work at the commencement of the voyage.

As it was considered inexpedient or found impossible in 1867 to alter the scales of diet then, as now, in common use afloat, legislative means were adopted to increase the quantity and ensure the good quality of the lime and lemon juice served out to sailors by Act of Parliament, this juice, fortified by a small percentage of alcohol, being considered, as a natural combination, the best and most convenient antiscorbutic. It is, however, as was pertinently remarked by, I think, Dr. Domett Stone some years ago, but "an antidote for a poisonous diet," and though its administration must, under existing circumstances, continue to be recommended and enforced, it is astonishing to me that shipowners do not so alter their diet scales as to precipitate the entire abolition of these vexatious (and to them sometimes costly) antiscorbutic clauses of the Merchant Shipping Acts. Meanwhile, as long as these clauses (necessitated by the monotony or bad quality of the food provided) are in force, I think it may be honestly maintained that the direct causes of sea-scurvy, as it exists in the present day, are purely preventable, if the authors thereof are not sufficiently punishable.

\section{CONGENITAL LUXATION OF THE CRYSTALLINE LENS.}

BY JABEZ HOGG,

SURGEON TO THE ROYAL WESTMINSTR OPHTHAXMIC HOSPITAL, RTC.

Traumatic luxation of the lens the ophthalmic surgeon is frequently called upon to treat in hospital, and it is observed that accidents of the kind are almost invariably due to blows on the eye; the lens is loosened from its attachments, and drops down behind the pupil, or is forced through it into the anterior chamber, or lodges in a pouch between the sclerotic and conjunctival coats. The patient 